DOI: $10.17805 /$ zpu.2016.2.3

\title{
Образование для XXI века: парадигмы профессора И. М. Ильинского
}

\author{
С. И. ПЛАКСИЙ
}

\author{
(НАЦИОНАЛЬНЫЙ ИНСТИТУТ БИЗНЕСА, Г. МОСКВА)
}

В статье анализируется научный вклад профессора И. М. Ильинского, доктора философских наук, профессора, ректора Московского гуманитарного университета, главного редактора журнала «Знание. Понимание. Умение», в разработку проблем современного высшего образования.

Для успешной реальной модернизации российского высшего образования нужны, вопервых, идеи, адекватные необходимости опережающего развития образования, во-вторых, их теоретическая проработка, а в-третьих, требуется, чтобы эти идеи и построенная на их основе наука образования сочетались с практикой и овладели умами тех, кто руководит образованием, и тех, кто им реально повседневно занимается (учителей, преподавателей и т. д.).

Поиску новых парадигм качественного образования, сориентированного на реалии современного общества и перспективы развития цивилизации, посвящены философские исследования И. М. Ильинского. Он выдвинул, обосновал немало интересных и плодотворных идей, которые имеют существенное теоретическое и практическое значение.

И. М. Ильинский сформулировал новую парадигму педагогики понимания и сотрудничества, включающую в себя триаду “знание - понимание - умение», переосмысление предметности и содержания образования, его актуализацию, отношение к студенту как к личности, как к полноправному и полноценному партнеру в системе образования. Предложил и обосновал образовательную парадигму, имеющую более широкий контекст, чем педагогическая парадигма, и охватывающую все аспекты образования (от финансовых, организационных, правовых до содержательных и воспитательных). Впервые в отечественной литературе системно исследовал истоки возникновения, природу и смысл, право- 
вые основы и экономическую сущность негосударственного (прежде всего высшего) образования.

В его трудах сформулирована современная парадигма образования для XXI в., миссией которого является обеспечение устойчивого развития общества и личности, а основными чертами становятся опережающий характер, гуманизация, непрерывность, развивающее, социально ответственное, личностно ориентированное образование, приводящее к достижению обучающимися уровня понимания, саморазвития и самореализации на базе широкого, фундаментального, открытого многовариантного обучения, в котором приоритет отдается творчеству, пониманию смыслов и инновациям.

Ключевые слова: Игорь Михайлович Ильинский; парадигма образования; российское высшее образование; «Знание. Понимание. Умение»; проблема понимания; научный вклад

\section{ВВЕАЕНИЕ}

$\mathrm{O}$ беспечить качественное образование XXI в. невозможно путем организационных и экономических изменений, внедрения большого числа проверочных и иных бюрократических процедур, отчетов, реализации пожеланий и указаний неких руководителей, в основе которых лежит личный опыт и разрозненные представления. Образование задыхается под валом бесконечных бумаг и организационной суеты по их выполнению. Непосредственно образованию как творческому процессу сотрудничества педагогов и обучающихся уделяется все меньше внимания. В учебных заведениях львиную долю времени сотрудников от руководителя до преподавателей занимает изучение и сочинение огромного числа нормативных документов и иных бумаг. Следует вернуть собственно образование в центр внимания всех его субъектов начиная от министра и кончая обучающимися. При этом необходимы новые парадигмы для перехода к новому качеству образования.

Аля успешной реальной модернизации российского высшего образования нужны, во-первых, идеи, адекватные необходимости опережающего развития образования, во-вторых, их теоретическая проработка, а в-третьих, требуется, чтобы эти идеи и построенная на их основе наука образования сочетались с практикой и овладели умами тех, кто руководит образованием, и тех, кто им реально повседневно занимается (учителей, преподавателей и т. А.).

\section{ПАРАДИГМА Т. КУНА И КААССИЧЕСКАЯ ПАРААИГМА ОБРАЗОВАНИЯ}

Аалеко не случайно в некоторых работах об образовании появилось слово «парадигма». Оно было введено в научный оборот Т. Куном, который предлагал в качестве концептуального модуля науки брать не отдельную теорию, а совокупность теорий, составляющих некоторое метатеоретическое единство - парадигму, которая базируется на разнообразных идеях и теоретических разработках в научном сообществе. Период «нормальной науки» отличается накоплением научных результатов по стандартным методикам и образцам, тогда как смена парадигм означает научную революцию, коренную ломку, новую интерпретацию теоретических и практических достижений. «Под парадигмой, - пишет Т. Кун, - я подразумеваю признанные всеми научные достижения, которые в течение определенного времени дают научному сообществу модель постановки проблем и их решений» (Кун, 1977: 11).

В буквальном смысле слова парадигма - это модель, образец. Возникновение новых парадигм является реакцией на кризис, попыткой выхода из него. Часто кризис разрешается именно благодаря новым парадигмам. Т. Кун отмечает: «...Переход от парадигмы в кризисный период к новой парадигме, от которой может родиться новая традиция нормальной науки, представляет собой процесс далеко не кумулятивный 
и не такой, который мог бы быть осуществлен посредством более четкой разработки или расширения старой парадигмы. Этот процесс скорее напоминает реконструкцию области на новых основаниях, реконструкцию, которая изменяет некоторые наиболее элементарные теоретические обобщения в данной области, а также многие методы и приложения парадигмы» (там же: 120).

Вывод Т. Куна о том, что «ни одна парадигма никогда не решает всех проблем» (там же: 150), но конкурирующие парадигмы могут дополнять друг друга, становиться средством выражения и распространения научной теории, чрезвычайно важен для науки об образовании, где есть концептуальные идеи, но их сторонники пока не достигли критической массы, способной преодолеть кризис.

Со времени И. Канта и В. Гумбольдта классической парадигмой образования является система идей, связывающая учебную деятельность и научные исследования. По мысли В. Гумбольдта, университет должен сочетать «объективную науку с субъективным образованием» (Гумбольдт, 2002: Электронный ресурс). Исследователь ищет истины, преподаватели принимают и транслируют их, а студенты критически впитывают последние достижения науки. Предлагалась тесная связь исследований и преподавания, а в ХХ в. постепенно исследования стали включаться непосредственно в обучение. Идея «образование через научные исследования» ныне лежит в основе реформ высшего образования в развитых странах и лучших университетов. Только по этому пути может идти опережающее обучение. Изложенная парадигма в XXI в. одна из ключевых. Исследовательское образование ныне как никогда актуально. Но, во-первых, оно не может стать массовым, а во-вторых, нужны и другие продвинутые парадигмы.

Одной из устоявшихся парадигм на протяжении двух веков было определение образования через формирование знаний, умений и навыков учащихся. При любом разговоре о повышении качества образовательной деятельности воспитателей, учителей, профессоров имеется в виду двусторонний процесс: а) поиск средств, форм и методов радикального изменения и усовершенствования знаний, умений и навыков ребенка, поступившего в школу, выпускника школы или среднего специального учебного заведения, студента вуза; б) приведение знаний, умений и навыков в соответствие с достижениями конкретных наук и потребностями современного производства. Педагогический смысл этой теории сохраняется даже и в инновационных проектах новых методов обучения (компьютеризация, аудиовизуальные средства обучения и т. п.).

На всех этапах образовательной системы (от школы до вуза) главными в предметности педагогической деятельности остаются ученик - как объект приложения педагогических усилий субъекта (учителя, преподавателя) и учебный предмет - как средство так называемой социализации ученика и воспитанника, т. е. адаптации к сложившимся формам социальной жизни.

Т. Кун отмечал, что развитие науки происходит путем разработки и смены парадигм, в рамках которых проводятся исследования и выдвигаются концепции (Кун, 1977: 18). Поиску новых парадигм качественного образования, сориентированного на реалии современного общества и перспективы развития цивилизации, посвящены философские исследования И. М. Ильинского.

\section{ТРУАЫ И. М. ИАЬИНСКОГО ОБ ОБРАЗОВАНИИ}

Игорь Михайлович Ильинский выдвинул, обосновал немало интересных и плодотворных соображений, даже парадигм, которые имеют существенное теоретическое 
и практическое значение. Коротко назову лишь некоторые из относящихся к сфере образования.

Во-первых, он сформулировал новую парадигму педагогики понимания и сотрудничества, включающую в себя триаду «знание - понимание - умение», переосмысление предметности и содержания образования, его актуализацию, отношение к студенту как к личности, как к полноправному и полноценному партнеру в системе образования (Ильинский, 2014).

Во-вторых, И. М. Ильинский предложил и обосновал образовательную парадигму, имеющую более широкий контекст, чем педагогическая парадигма, и охватывающую все аспекты образования (от финансовых, организационных, правовых до содержательных и воспитательных) (Ильинский, 2002а). Это креативно-развивающая парадигма образования, связанная с необходимостью устойчивого развития открытого и глобального мира, с актуальностью не только экономики знаний, к чему мы уже привыкли на словах, но и понимания происходящего и должного в широком контексте. Кстати, идея о связи образования с устойчивым развитием общества была выдвинута и всесторонне обоснована Игорем Михайловичем еще в 2001-2002 гг. (Ильинский, 2006), а в 2005 г. ООН предложила стратегию на ближайшее десятилетие под названием «Образование для устойчивого развития».

В-третьих, он впервые в литературе системно исследовал истоки возникновения, природу и смысл, правовые основы и экономическую сущность негосударственного (прежде всего высшего) образования (Ильинский, 2004).

Ряд опубликованных им книг по проблемам образования можно назвать уникальными по сплаву теории и практики.

Книги И. М. Ильинского «Образовательная революция» (Ильинский, 2002а) и «Негосударственные вузы России: опыт самоидентификации» (Ильинский, 2004), его многочисленные новаторские статьи стали заметным событием в науке и в жизни образовательного сообщества, открыли новые смыслы, повысили уровень адекватности понимания образования в контексте общественной жизни.

Философское исследование И. М. Ильинского, представленное в книге «Образовательная револючия», посвящено поиску новых парадигм образования, сориентированного на реалии современного общества и перспективы развития иивилизачии. Необходимость смены парадигмы означает для автора осознание, понимание несоответствия ранее сложившихся и ставших традиционными представлений образовательной практики новым реалиям. С одной стороны, И. М. Ильинский показывает мировые, исторические тенденции, следствием которых может стать будущее состояние образования, а с другой - из современных отечественных событий и условий он прогнозирует грядущие возможные и необходимые изменения. Такова многослойность книги.

Преодоление нынешнего кризиса развития человеческой цивилизации, переход к новой парадигме устойчивого развития системы «природа - общество - человек» невозможно без преодоления кризиса системы образования, которая продолжает готовить людей к жизни в рамках старой концепции экономического количественного роста, безудержной эксплуатации природы, бездумного потребления. Вектор науки и образования пока имеет одно направление: как больше взять от природы. А он должен быть направлен на то, как больше дать природе, обществу, другим людям, самому себе в основной своей ипостаси - человека думающего. Это магистральный путь преодоления кризиса образования, который не может быть внутренним делом его собственной структуры и среды, поскольку является частью общественного цивили- 
зационного кризиса. Осознание этого происходит, но пока лишь отдельными учеными. И. М. Ильинский в своей книге пишет: «Аействительный кризис образования практически не осознан. Ибо он связан с пониманием смысла истории, который и поныне видится в индивидуальных целях и практической деятельности людей, стремящихся прежде всего и главным образом приспособиться к жизни через борьбу за существование и овладение жизненными ресурсами, к материальному благополучию и максимальной прибыли. Никаких высших целей, связывающих человека с более широким пластом реальности, никаких идеалов пока не просматривается» (Ильинский, 2002a: 174).

В слово «кризис» вкладывается разный смысл. Аля одних - это элементарная грамотность, для других - уровень и качество среднего образования, для третьих - развитость и качество всей системы образования и т. А., другими словами, широкое поле различий.

И. М. Ильинский отмечает: «...новые технологии предъявили новые требования к работнику в плане не только количества знаний, умений, навыков, но и к его творческим способностям и личным качествам (инициативность, предприимчивость, активность). Это вызвало острое напряжение в отношениях системы образования с рынком труда, производством, которое определили словом “кризис” (там же: 173-174).

На пути совершенствования уже существующих, традиционных структур кризис не будет преодолен. Нужны не отдельные улучшения, частичное реформирование, а революционные изменения, скачок во всех сторонах, элементах и аспектах образования. Образование, если оно претендует на адекватность обеспечения будущего Аля человечества, должно соответствовать новой парадигме развития, а следовательно, «должно быть не просто модернизировано или реформировано, а стать другим» (там же: 175$)$.

Аля преодоления сущностных черт кризиса образования должна быть решена задача корректировки смысла истории и разработки новой парадигмы развития человечества, идея и основы которой уже существуют. Это и будет фундамент нового мышления и осознания; это и будет базис мировоззренческой части «другого» образования. Именно в этом плане прежде всего нужна и уже началась образовательная революция, которая, однако, не может произойти в отрыве от решения более общего императива - выживания человека в XXI в. путем перехода к новому типу социоприродного гомеостаза, новому типу механизма устойчивости цивилизационного развития. Но без опережающего развития адекватных знаний, общего интеллекта человечества, соответствующей системы и содержания образования новый тип развития не сможет пробить себе дорогу, ибо это не может произойти в стихийном режиме. Новый тип развития должен быть осознан, спроектирован, обоснован, понят и принят основной массой жителей планеты. А это возможно лишь в том случае, если соответствующим образом заработает система образования.

\section{КАКОЕ ОБРАЗОВАНИЕ - ТАКОЕ И ОБЩЕСТВО}

Парадигмы образования должны вытекать из кардинально изменяющихся, но пока еще слабо понимаемых цивилизационных парадигм. Значит, общество должно сформулировать новую парадигму устойчивого развития (в трактовке докладов Римского клуба и Международной комиссии по окружающей среде и развитию) и, как следствие (а возможно, как первоисточник), новую парадигму образования, как пишет И. М. Ильинский, основываясь на факте, что «человек - существо чрезвычайно 
легко программируемое», а «современное образование - мощнейшее средство программирования».

И. М. Ильинский обосновывает необходимость «образовательной революции», основанной на понимании «новой миссии образования», которая, в свою очередь, должна формировать «новую систему ценностей», «новую этику», «новую предметность образовательной деятельности» (т. е. ответ на вопрос «чему обучать?») и обязательно - «человекообразующее и обществообразующее знание». Автор доказывает, что новая образовательная парадигма должна включать несколько основных идей и ПодХодов.

Он перечисляет некоторые из них:

- новый взгляд на миссию образования в XXI в.;

- новый взгляд на предмет и конечные цели образования;

- новый взгляд на уровни образования;

- новый взгляд на роль социально-гуманитарного знания;

- новый взгляд на учебные задачи и средства решения этих задач.

Системообразующей идеей организации и содержания образования, по мнению автора, должна стать идея устойчивого развития, без которого у человечества короткое будущее. Необходимость выживания человека через устойчивое развитие ставит перед образованием XXI в. задачу: довести до сознания людей то, что уже ясно объективно, но не принимается основной массой людей.

Как считает И. М. Ильинский, сегодня «мир оказался на краю катастрофы, его губит принцип «практической полезности», «безудержный рационализм». А образование стало обслуживать государственную парадигму развития. «Сегодняшняя парадигма образования, - пишет автор «Образовательной революции», - реализует в основном механистический (линейный, предопределенный) характер развития общества и науки, строится на принципах оптимизации, интенсификации, унификации учебного процесса, типизации и стандартизации учебных планов и программ» (Ильинский, 2002: 223). В образовании упускается главное - ориентация на глубокое понимание действительности и подготовка к реалиям развития в ближайшие десятилетия.

В результате неадекватности содержания образования обостряется дефицит «людей широкой эрудиции», т. е. людей, способных глубоко понимать широкий круг общезначимых проблем общества. И в первую очередь главные проблемы выживания человечества.

Парадигма выживания планеты и человечества, ее основные принципы должны быть сформулированы учеными и переданы системой образования, приняты как отправные точки для дальнейшего познания молодежью саморазвития. По этому пути должна идти вся система образования. Но полное понимание сути может дать только высшая школа. Концепция устойчивого развития должна стать основой универсального миропонимания и мироустройства. Она отличается от всех предыдущих идеологий, претендовавших на универсализм и глобализм, тем, что в главном и основном носит социальный, а не политический характер, ориентирует на развитие и оптимальное использование человеческого потенциала в гармонии с природой.

Авижение «Образование для устойчивого развития» зародилось еще в 1990-е годы. ООН объявила декаду «Образование в интересах устойчивого развития» (2005-2014 гг.). В российском образовании эта идея пока находится на стадии перехода от скепсиса к снисходительному допущению возможности допущения. Образова- 
тельные власти и общественность провозглашают свою приверженность устойчивому развитию. Так, в резолюции Всероссийской научно-практической конференции «Образование для устойчивого развития в высшей школе России: научные основы и стратегия развития» (МГУ, октябрь 2008 г.) говорится: «Идеология образования для устойчивого развития полностью созвучна основным положениям приоритетного национального проекта "Образование”, успешно осуществляемого в настоящее время в России». Однако на практике явного продвижения пока не наблюдаем. Не случайно авторы доклада по устойчивому развитию России в 2013 г. отмечают, что экологическое образование подменяет собой образование для устойчивого развития (ОУР) (Аоклад о человеческом развитии ..., 2013). В высшем образовании необходима разработка новых или включение ОУР в существующие стандарты, интеграция его в различные дисциплины, переподготовка кадров, учебных и методических материалов. Авторы доклада пишут: «Реализация принципов устойчивого развития при поддержке со стороны государства создает предпосылки для нового этапа әкологизации образования в России, суть которого - в радикальной модернизации системы обучения посредством экологизации всех преподаваемых дисциплин средней и высшей школы (от математики до лингвистики)» (там же: 11$)$.

Между тем в содержании высшего образования ориентация на устойчивое развитие не наблюдается ни в России, ни в других странах. Система высшего образования ведет обучение и воспитание студентов, абсолютно не задумываясь о том, что ждет выпускников через 20-30-40 лет, т. е. в период их активной трудовой деятельности. Не учитываются и перспективы исчерпания жизнедеятельности в рамках нынешней системы координат с нарастанием уровня потребления, в то время как многие природные запасы и возможности иссякают, уменьшаются, как шагреневая кожа.

Почему знания о пределах роста и устойчивом развитии необходимо в большом объеме включить в высшее (да и в среднее) образование? Потому, что понимание всей глубины проблем нынешней молодежью должно стать залогом возвращения в пределы роста.

Современные знания, применение методов научного, системного мышления позволяют согласиться с неприятным выводом: постоянный материальный рост уже через несколько десятилетий достигнет определенного предела. Как считают А. Медоуз, Й. Рандерс и А. Медоуз, текущие тенденции приведут мир к выходу за пределы и катастрофе в результате безнадежных попыток победить экологические пределы. Ситуация в ближайшие десятилетия станет существенно хуже (Медоуз и др., 2007).

Иейтмотивом образования XXI в. должно стать распространение знаний и понимание того, что личность не только средство, но и самоцель всех человеческих усилий, но люди живут на планете с ограниченными ресурсами, и они не могут бесконечно и все больше потреблять их, не ограничивая себя. Разумное ограничение производства и потребления благ, природных богатств, их восстановление, развитие должны быть тесно связаны с заботой о сохранении богатств Земли, природы, гуманизмом, сотрудничеством, сосуществованием не только людей, но и всего живого. Качественное высшее образование невозможно без знания, понимания проблем устойчивого развития и включенности в их решение.

Образование для устойчивого развития неизбежно связано с гуманизацией всех его сторон, в том числе гуманитаризацией содержания. И. М. Ильинский подчеркивает: «...основное отличие прежней (действующей) концепции образования от его новой 
парадигмы заключается в том, что если прежняя парадигма в своей основе и содержании была научно-технократической, то новая по своему содержанию является (прежде всего) гуманитарной.

Это различие не следует понимать таким образом, что точные науки и естествознание теряют свою ценность, что социально-гуманитарное знание вытесняет их и тем более заменяет. Просто этот вид знания (о человеке, культуре, обществе, бытии, сознании, политике, истории) начинает занимать и со временем займет подобающее ему место и роль в сознании личности и общества, их развитии... Сегодня стоит вопрос о равноправии и равнозначности этих двух видов знания, а не о превосходстве одного над другим, об их синтезе» (Ильинский, 2002а: 240).

\section{ПРОБАЕМА ПОНИМАНИЯ}

А что должно быть главным в обучении: знания, умения, навыки, компетенции? Все это важно. Но недостаточно. Главным должно быть достижение уровня понимания. Сегодня мало давать знания, формировать умения и компетенции. Необходимо научиться «обучать пониманию». Эту плодотворную идею обосновывает и разрабатывает И. М. Ильинский. Он пишет: «...на обыденном уровне сложилось представление, что мы сегодня очень много знаем, а значит, если не все, то многое понимаем. На первый взгляд так оно и есть. Но спросим себя: “Что мы знаем?” Сплошь и рядом мы знаем слова и названия явлений, событий, процессов, но не их содержание, не глубинный смысл, т. е. сущность. В данном случае мы говорим о подмене знания сущности предмета знанием его названия, которое принимается за понимание. На самом деле это иллюзия знания, иллюзия понимания... Понимание - это синоним творчества, это творческий процесс, это огромный труд. <..> В чем высший смысл образования, чему надо учить, что надобно непременно не только знать, но и понимать - вот в чем, если говорить предельно кратко, заключается суть кардинального, революционного преобразования образования в XXI в., с помощью которого должно быть столь же серьезно, на основе новой парадигмы преобразовано общество» (Ильинский, 2002b: 24).

Глубина понимания (явлений и событий, прошлого и настоящего) зависит не столько от количества имеющейся информации, сколько от духовно-нравственной зрелости и интеллектуального, творческого потенциала «понимающей» личности, умения перерабатывать информацию с позиции ее смысловой нагрузки.

На наш взгляд, вместо превалирующих сейчас в образовательных программах принципов свободного рынка, развития и наращивания масштабов производства в основу концепции нового качества образования должны лечь идеи и принципы устойчивого развития.

Конечно, концепция устойчивого развития, определяющая стратегию выживания человечества, устанавливающая новые принципы отношения человека к природе, к другим людям, к самому себе, будет уточняться и развиваться, что потребует многолетней и постоянной целенаправленной научной деятельности, но уже добытые знания и вырабатываемые принципы должны быть не просто использованы в учебном процессе, а пронизывать все содержание общего, а также специального гуманитарного, естественно-научного, технического, сельскохозяйственного, медицинского образования. Это не просто экологическое обучение и воспитание, а иная философия, методология, теория и практика всего образования, всей его многообразности, многоаспектности, на всех уровнях и во всех формах. 
Одной из самых привлекательных сторон предложенной И. М. Ильинским концепции образования является требование синтеза разума и чувства, знаний и воспитания: «Обучение без воспитания ущербно, само по себе оно может принести больше пользы, чем вреда, так как знания могут быть использованы не во благо, а во зло. И если мы говорим о человеке, то одного ума для его характеристики недостаточно. НеобхоАимо иметь в виду не только его умственные способности, но и его эмоциональную, чувственную, духовную стороны, которые создаются не столько обучением, сколько (прежде всего) воспитанием. Но этим не занимаются ни школа, ни вуз... Система образования обращена только к одной половине человеческого мозга, где размещается это самое "ratio" - разум. Аругая доля, “отвечающая" за чувства и эмоции, не задействована или задействована крайне плохо... В итоге мы видим мир и понимаем жизнь однобоко, частично, а не в полном объеме» (Ильинский, 2002а: 37).

Автор «Образовательной революции» видит смысл современного образования в научении творчеству через активизацию совести, разума и эмоций, которые в своем единстве способны обеспечить успешность процесса приспособления к изменяющимся и часто неизвестным условиям, достижение лучших результатов. «Творческая личность» - понятие высокого порядка и скорее редкое исключение, чем широко распространенное правило. Но определенный уровень творческих способностей характерен для многих. По его мнению, ставить перед образованием задачу развития творческих способностей учащихся не только возможно, но и необходимо.

Усиление воспитательной составляющей образования также связано с гуманитаризачией его содержания. Как подчеркивает И. М. Ильинский, «основное отличие прежней (действующей) концепции образования от его новой парадигмы заключается в том, что если прежняя парадигма в своей основе и содержании была научно-технократической, то новая по своему содержанию является, прежде всего, гуманитарной» (там же: 240). Она должна ориентировать на образовывание человечной личности, способной быть в гармонии с другими людьми и природой.

В своей книге И. М. Ильинский обосновывает, что составными компонентами новой парадигмы образования должны стать идеи об опережающем его характере, предполагающем такой уровень творческого владения фундаментальными и актуальными знаниями, который позволил бы человеку не только успевать за лавинообразными изменениями, но и опережать, формируя как новое производство, технику и технологии, так и новые способы освоения знаний. Образование «должно носить упреждающий, опережающий характер, способствовать конструированию и строительству новой реальности» (там же). Только в этом случае оно обеспечит опережающее развитие качеств человека, его интеллекта.

Автор настаивает на необходимости «сознательно опережающего» развития образования как основы развития общества. Ведь именно образование по самой своей сути призвано работать на будущее, закладывая основу предстоящих изменений в обществе, предопределяя в конечном счете «человеческую составляющую» характера и темпов его развития.

Опережающий характер образования означает, что оно не только успешно адаптируется к внешней среде, соответствует потребностям личности, общества, производства, но и само активно влияет на состояние личности и общества, предопределяет и формирует их потребности, исходя из научного предвидения, прогнозирования ближайших и отдаленных перспектив цивилизационного развития, а не только запросов производства. Образование должно строиться исходя их стратегических приори- 
тетов развития общества, быть «впередсмотрящим». Реальное сегодняшнее образование - это проекция будущего.

Еще одной составляющей новой парадигмы образования является идея непрерьљного образования. И. М. Ильинский показывает реальные пути перехода от старой конструкции «образование на всю жизнь» к новой конструкции - «образование через всю жизнь». Непрерывное образование означает, что человек учится постоянно, без относительно длительных перерывов, переходит от одного вида образовательной деятельности к другому, с более низкой ступени самообразования на более высокую. Непрерывность образования должна обеспечить максимальную возможность многомерного движения личности в интеллектуальном пространстве социума. Уже сегодня образование, не ограниченное жесткими сроками обучения, приобретает черты постоянной составляющей жизнедеятельности многих людей. Мало того, трудно представить себе процесс совершенствования современной личности без непрерывного образования и самообразования.

Внутренний смысл революции образования И. М. Ильинский видит в переходе на более высокий уровень понимания знаний. Сегодня каждый умственно и психически здоровый человек знает больше самых знаменитых мудрецов древности. Но всех ли научают эти знания уму? Качественное образование - не то, которое предполагает запоминание как можно большего количества информации, и не то, чему человека учили, а то, сколько и как им понято, освоено. Не может быть образование качественным, если оно сводится к обучению, а его результатом становятся новые знания без их глубокого осмысления и понимания. Между тем способность понимать целенаправленно не развивается ни в школе, ни в вузе. Хотя опыт педагогов-новаторов ясно показывает, что если образовательный процесс сориентирован на понимание, а не запоминание материала, то эффективность обучения резко возрастает и преодолевается «отчуждение» студента, когда он воспринимает и знания, и преподавателя как чуждую реальность. Понимание предмета приводит к взаимопониманию студента и преподавателя. Но есть и обратная связь.

Суммируя свои рассуждения на эту тему, И. М. Ильинский пишет: «Понимание имеет несколько уровней; понимать - значит приписывать собственный смысл познаваемой реальности к известному знанию; осознавать - значит преобразовывать смыслы; понимать - значит творить. Процесс понимания и процесс творчества совпадают, они тождественны, а понятия «понимание» и «творчество» - синонимы. Вот почему в предметную область новой парадигмы образования я включил задачу развития творческих способностей личности. Надо преодолевать фрагментарное представление о мире, упорядочивать нашу жизнь, придавая ей иные, более высокие смыслы. Учить человека работать, образно говоря, не только с микроскопом, но и владеть телескопом - видеть мир целостным и гармоничным, не теряя в нем себя самого. Как это делать в школе и вузе - другой вопрос. Надо создавать специальные методики, тренинги. Но без массового развития творческих способностей мы не сможем повысить уровень понимания знаний и происходящего, а значит, не сможем поставить серьезный заслон поощрению абсурдной действительности» (там же: 276).

Автор «Образовательной революции» предлагает заменить информачионнотранслируюшую педагогическую парадигму на личностно-созидательную педагогику понимания. Она предполагает не только полное признание значимости личностных образовательных ценностей, уход от главенства внешней по отношению к учащимся целесообразности, которую им не дано понять, но и расставание со «священными ко- 
ровами» педагогики, которыми на протяжении веков были знания, умения, навыки и предметность в преподавании. Он пишет: «Царствовавшая три столетия парадигма развития общества и вытекающая из нее (определяемая ею) прежняя образовательная парадигма исчерпали себя... Ключевым пунктом обучения становится степень овладения знанием, глубина понимания...» (там же: 246).

Концепция понимания в образовании, разрабатываемая И. М. Ильинским, привела к созданию журнала «Знание. Понимание. Умения», который издается в Московском гуманитарном университете с 2004 года. В связи с десятилетием журнала Игорь Михайлович писал: «Конечный смысл образования - не знания, а именно понимание... Кризис понимания берет свое начало в избытке информации, и идти дальше в образовании и науке путем наращивания только компонента знаний бессмысленно, это значит, что пониманию надо учить. Вуз должен через знание развивать мышление до уровня понимания» (Ильинский, 2014: 10).

\section{МИФОАОГИЯ НЕГОСУААРСТВЕННОГО ОБРАЗОВАНИЯ}

В книге И. М. Ильинского «Негосударственные вузы России: опыт самоидентификации» впервые в литературе системно исследуются истоки возникновения, природа и смысл, правовые основы и экономическал сушность негосударственного (прежде всего высшего профессионального) образования (Ильинский, 2004).

Как отмечает автор, по поводу «негосударственного» образования заинтересованными в его ликвидации конкурентами создалась целая мифология, с помощью которой в общественном сознании и у руководителей страны укрепляется негативный образ «негосударственного» образования как явления противоестественного, вредного, которому очень скоро придет конец. Он называет три главных мифа о негосударственном высшем образовании:

Миф первый. На волне демократизации и перехода к рыночным отношениям в России возникло «странное» явление - «негосударственное» (оно же, как предлагают думать обывателю мифотворцы, - «коммерческое», «частное») образование, которое чуждо российской действительности и не имеет перспектив. Его надо рассматривать как наступление на бесплатное, доступное всем государственное образование. Явление это, якобы противоестественное в принципе, не приживается на Западе, а там, где прижилось, постепенно отмирает.

Миф второй. «Негосударственные» вузы - это, в сущности, нечто совсем иное, нежели государственные, они по определению не могут быть «хорошими», потому что являются «частными», «коммерческими» и созданы для извлечения прибыли и обогащения нечистоплотных людей. «Негосударственный»- значит теневой, по сути дела, криминальный.

Миф третий. Качество образования в «негосударственных» вузах крайне низкое. В этих вузах учатся сплошь дети «новых русских» и всяких нуворишей, вынужденных платить за учебу своих чад, так как те плохо подготовлены, или в них учатся сплошь бездари и отбросы, «отсевки», не прошедшие в госвузы по конкурсу.

Как справедливо отмечает профессор И. М. Ильинский, негосударственный вуз имеет свою специфику. Это организация саморегулируемая, т. е. самостоятельно, без команды извне, реагирующая на внешние воздействия (изменения законов, политической и экономической ситуации, конъюнктуры на рынке образовательных услуг).

Второй существенный признак негосударственного вуза состоит в том, что он организация самофинансируемая, т. е. способная полностью, без помощи государст- 
ва покрывать свои расходы как по оказанию образовательных услуг студентам, так и по созданию, укреплению материальной базы, инфраструктуры для качественного образования.

Третий признак состоит в том, что негосударственный вуз - организация предпринимательская, так как он изначально вынужден базироваться на экономической состоятельности, действовать расчетливо, заботясь о конечном результате и эффективности.

В качестве четвертого признака называется возможность вуза по своему усмотрению определять содержание учебных программ, формы и методы организации учебного процесса и научно-исследовательской работы, способы проверки знаний у студентов.

И. М. Ильинский не только разрабатывает концептуальные основы развития, модернизации образования на основе новых парадигм, но и конкретизирует их применительно к высшему учебному заведению, а также реализует на практике на основе четко формулируемой стратегии Московского гуманитарного университета.

Стратегия - это относительно долгосрочный план действий, определение приоритетов, перспективных задач, ресурсов и последовательности шагов по достижению поставленных стратегических целей. В образовательной стратегии вуза важно достичь не только внешних признаков успешности, стабильности, конкурентоспособности, но и соответствовать миссии высшего образования с его содержательными сторонами. Поэтому современный вуз должен найти ответы на вызовы времени с позиции будущего и адекватно организовать свою работу. Стратегия вуза должна обеспечивать его развитие, переход к новому качеству, конкурентоспособность на рынке образовательных услуг. Разрабатывая стратегию, И. М. Ильинский находит адекватные ответы на вызовы времени с позиции будущего, четко видит и излагает миссию и пути модернизачии высшего образования.

Модернизачия - это изменения, адекватные современности, введение различных усовершенствований. Применительно к образованию модернизация означает, во-первых, его адаптацию к изменившимся социально-экономическим и государственно-политическим условиям развития России. Во-вторых, освоение опыта модернизации образовательной сферы, накопленного в других странах. Но она не предполагает подражательства. Аля университета важны сохранение, поддержание, поиск самобытности, бережное отношение к оправдавшим себя традициям, отказ от единообразия, вариативность в решении проблем и задач. Концепция модернизации в университете это не просто программа назревших перемен, изменений в действиях, это также новая философия высшего образования, которая определяет новые цели и новые ценности, вводит в контекст всеобъемлющих мировых модернизационных процессов. Таков общий контекст модернизации в Московском гуманитарном университете. Речь идет об обновлении образования в целом, т. е. всех его сторон: учебной, воспитательной, научной, управленческой, финансово-экономической, хозяйственной. Все эти стороны взаимосвязаны и работают на образование более совершенных личностей студентов. Успех модернизации высшего учебного заведения возможен только на базе лучшего мирового и отечественного опыта и требует больших затрат средств и огромной энергии всех преподавателей, сотрудников и студентов, умелого менеджмента, который в условиях нынешней России не может не быть антикризисным. Иначе говоря, в условиях нынешнего этапа развития успех негосударственного вуза предполагает разработку и реализацию антикризисной стратегии и кризисного управления. 
Модернизачия высшего образования невозможна без активного уиастия студенmob. Поэтому особое значение Игорь Михайлович придает воспитанию студентов в реалиях современности и с опорой на идеалы.

Единство обучения и воспитания, «живой характер» образования, по мнению И. М. Ильинского, должна обеспечить «педагогика понимания», которая предполагает не только сотрудничество и взаимопонимание между преподавателем и студентом, но также адекватное содержание и технологии обучения и воспитания. Нынешняя педагогика, утверждает он, должна отойти от жестких технологий навязывания универсальных представлений о ценностях культуры, в том числе и универсальных социальных и гуманитарных знаний. Необходимо осваивать «мягкие» технологии понимания и интерпретации ценностей других культур, других взглядов и концепций. Автор говорит о «понимающем» знании, о педагогике понимания.

\section{ЗАКАЮЧЕНИЕ}

Прочитав и проанализировав книги И. М. Ильинского «Образовательная революция» и «Негосударственные вузы России: опыт самоидентификации», а также его статьи, приходишь к выводу о том, что перед тобой новое явление в науке и практике образования. В его трудах сформулирована современнал парадигма образования для XXI в., миссией которого является обеспечение устойчивого развития общества и личности, а основными чертами становятся опережающии характер, гуманизаиия, непрерывность, развиваюоее, сочиально ответственное, личностно ориентированное образование, приводящее к достижению обучаюшимися уровня понимания, саморазвития и самореализачии на базе широкого, фундаментального, открытого многовариантного обучения, в котором приоритет отдается творчеству, пониманию смыслов и инновачиям.

Суть образовательной революции, по мнению И. М. Ильинского, не столько в совершенствовании форм и методов передачи знаний, в новых образовательных технологиях, механизмах финансирования, в изменениях в управлении учреждением, наращивании новых образовательных услуг, сколько в переосмыслении самой миссии образования, которая видится ему как спасительная для общества; в выработке новых отраслей знаний и создании новых учебных дисциплин, дающих не только знание, но и понимание смыслов, в том числе вызовов и угроз, следствием которых может быть мировая катастрофа. Устойчивое развитие общества может обеспечить устойчивое и инновационное образование, основанное на педагогике понимания. И наоборот.

Аоминирующей парадигмой в образовании, его перехода к новому качеству должна стать идея гуманизации (очеловечивания) всей системы, содержания, процесса и форм образования. На практике это означает, во-первых, перенос центра тяжести на потребности и интересы всех участников образовательного процесса (учащихся, студентов, педагогов), создание оптимальных условий для их развития и реализации; во-вторых, гуманизацию и демократизацию всех отношений в образовательном сообществе; в-третьих, гуманитаризацию образования (т. е. образование через призму человека, его гармонии с природой и обществом); в-четвертых, подход к конструированию содержания образования под углом зрения воспитания будущего человека, последующих поколений, перспектив человеческой цивилизации.

Аолжна быть преодолена неприкасаемость самого предмета учебной деятельности, схематично определяемого как знания, умения, навыки (ЗУН). На смену этой триаде придет иное определение сущности образования: 
- формирование у обучающегося общей картины мира, в которой особый акцент делается на прогноз перспектив развития мира, различных аспектов человеческой жизнедеятельности;

- усвоение некоторой системы знаний, которая может сегодня и завтра считаться необходимой и достаточной для того, чтобы человек являлся образованным;

- достижение понимания смыслов передаваемых знаний через создание ситуаций понимания, особенно в областях знания, связанных с обществом, человеком, природой;

- формирование навыков и умений приобретать новые знания, осмыслять их с позиции не только профессии и личной перспективы, но в контексте общественного развития и изменений в природе;

- развитие личности с целью повышения ее творческих способностей;

— переход от иллюзии знаний к пониманию, «обучение пониманию».

В XXI в. необходимо учить не только тому, что было и есть, а тому, что и как должно быть; учить не только сущему, но и должному; воссоздавать существующую структуру знаний таким образом, чтобы в нее были вплетены представления о новом устройстве общества, позволяющие ему преодолевать рассогласования в развитии.

На наш взгляд, новое качество высшего образования XXI в. - это гуманистически ориентированное, социально ответственное, развивающее образование, построенное на принципах духовно-этической доминанты; гармонизации человека с природой через усвоение современной научной картины мира и концепции устойчивого развития; предоставления возможности всем субъектам для беспрерывного саморазвития и самореализации на базе широкого, фундаментального, открытого, многовариативного обучения, в котором приоритет отдается творчеству и инновациям, которое носит опережающий, развивающий, гуманистический характер. При наличии таких свойств высшее образование способно совершить скачок к новому качеству, а следовательно, удовлетворять текущие и перспективные потребности личности, общества, производства.

Один из немногих исследователей и практиков, способных сформулировать парадигмы образования для XXI в., - профессор И. М. Ильинский. Его миссия спасительна для Московского гуманитарного университета, который выжил и инновационно развивается благодаря правильно выбранной, сформулированной и постоянно уточняемой ректором стратегии, ее настойчивой реализации на основе понимания, сотрудничества, творчества, обеспечивающих устойчивость и самосовершенствование в парадигме синергетического видения. Сформулированные в его трудах идеи и положения при их понимании могут и должны лечь в основу модернизации высшего образования России, которое нуждается в модернизации на основе устойчивого и опережающего развития, адекватного понимания.

\section{СПИСОК АИТЕРАТУРЫ}

Гумбольдт, В. фон. (2002) О внутренней и внешней организации высших научных заведений в Берлине / пер. с нем. С. Шамхаловой [Электронный ресурс]// Неприкосновенный запас. № 2 (22). URL: http://magazines.russ.ru/nz/2002/22/gumb.html (дата обращения: 12.02.2016).

Аоклад о человеческом развитии в Российской Федерации за 2013 г. (2013) / под общ. ред. С. Н. Бобылева. М. : ООО «РА ИАЬФ». 202 с.

Ильинский, И. М. (2002а) Образовательная революция. М. : Изд-во Моск. гуманит.-социальн. академии. 592 с. 
Ильинский, И. М. (2002b) XX век: кризис понимания. Аоклад на Международной научной конференции «Итоги ХХ века», посвященной 80-летию А. А. Зиновьева. Москва, МГСА, 15 ноября 2002 г. М. : Изд-во Моск. гуманит. ун-та. 32 с.

Ильинский, И. М. (2004) Негосударственные вузы России: опыт самоидентификации. М. : Изд-во Моск. гуманит. ун-та. 352 с.

Ильинский, И. М. (2006) Образование. Молодежь. Человек. М. : Изд-во Моск. гуманит. ун-та. 560 с.

Ильинский, И. М. (2014) «Знание - понимание - умение» как формула перспективной научной и образовательной политики // Знание. Понимание. Умение. № 1. С. 5-17.

Кун, Т. (1977) Структура научных революций / пер. с англ. И. З. Налетова. М. : Прогресс. $300 \mathrm{c.}$ $342 \mathrm{c}$.

Медоуз, А., Рандерс, Й., Медоуз, А. (2007) Пределы роста: 30 лет спустя. М. : Академкнига. Aата поступления: 15.02.2016 2.

EDUCATION FOR THE 21ST CENTURY:

THE PARADIGMS OF PROFESSOR I.M. ILINSKIY

S. I. PLAKSII

(NATIONAL INSTITUTE OF BUSINESS, Moscow)

The article examines the contribution Professor I. M. Ilinskiy, Doctor of Philosophy, Rector of Moscow University for the Humanities, Editor-in-Chief of 'Znanie. Ponimanie. Umenie' journal made to the study of contemporary higher education and its problems.

A combination of several factors is required to successfully modernize higher education in Russia. These include ideas that can guarantee proactive development of education; their theoretical background; and their implementation in the practice of both administrators and educators (school teachers, university faculty, etc.)

I.M. Ilinskiy's research in philosophy has been devoted to the search of new paradigms of highquality education focused on the contemporary realities and prospects of civilizational development. Professor Ilinskiy has advanced and made the case for a number of interesting and fruitful concepts and ideas which have proved significantly important on both theoretical and practical levels.

I. M. Ilinskiy has formulated the new paradigm of the pedagogy of understanding and cooperation. Based on the tripartite model of 'knowledge - understanding - skill', it rethinks the disciplinary basis of education, updates its content, calls for treating the student as a full-scale partner in the educational system and as a human being in his/her right. The paradigm of education as suggested by I.M. Ilinskiy is wider than the conventional paradigm of pedagogy, since it covers every aspect of educations, from finances, organization and legal status, to those dealing with its content and 'vospitanie' (personality development). Professor Ilinskiy was the first Russian researcher to provide a systemic study of the origins, nature, legal foundations of and the economic rationale for private education, primarily on the university level.

His works reveal the contemporary paradigm of the education for the 21st century, with sustainable development of societies and individuals as its mission, and the principal features including proactivity, humanization and lifelong learning. This socially and personally engaged education will help students achieve high levels of understanding, self-development and self-fulfilment on the basis of wide, fundamental and open multi-trajectory education which prioritizes creativity, innovation and comprehending the nature of things.

Keywords: Igor' Mikhailovich Ilinskiy; paradigm of education; higher education in Russia; Znanie. Ponimanie. Umenie; problem of understanding; research contribution

Humboldt, W. von. (2002) O vnutrennei i vneshnei organizatsii vysshikh nauchnykh zavedenii $\mathrm{v}$ Berline [On the Internal and External Organization of the Higher Scientific Institutions in Berlin]. 
Neprikosnovennyi zapas, no. 2 (22). [online] Available at: http://magazines.russ.ru/nz/2002/22/ gumb.html (access date: 12.02.2016). (In Russ.).

Doklad o chelovecheskom razvitii $v$ Rossiiskoi Federatsii za 2013 g. (2013) [A report on human development in Russian Federation in the year 2013]/ ed. by S. N. Bobylev. Moscow, OOO RA IL'F. 202 p. (In Russ.).

Ilinskiy, I. M. (2002a) Obrazovatel' naia revoliutsiia [The educational revolution]. Moscow, Moscow Academy for the Humanities and Social Sciences Publ. 592 p. (In Russ.).

Ilinskiy, I. M. (2002b) XX vek: krizis ponimaniia. Doklad na Mezhdunarodnoi nauchnoi konferentsii "Itogi XX veka», posviashchennoi 80-letiiu A. A. Zinov'eva. Moskva, MGSA, 15 noiabria $2002 \mathrm{~g}$. [20th century: The crisis of understanding. A paper presented at International conference "20th century: The Outcomes" in celebration of the 80th anniversary of A.A. Zinoviev. Moscow Academy for the Humanities and Social Sciences, November 15, 2002]. Moscow, Moscow Academy for the Humanities and Social Sciences Publ. 31 p. (In Russ.).

Ilinskiy, I. M. (2004) Negosudarstvennye vuzy Rossii: opyt samoidentifikatsii [Non-state Institutions of Higher Education in Russia: An Attempt at Self-identification]. Moscow, Moscow University for the Humanities Press. 350 p. (In Russ.).

Ilinskiy, I. M. (2006) Obrazovanie. Molodezb'. Chelovek [Education. Youth. Human Being]. Moscow, Moscow University for the Humanities Press. 560 p (In Russ.).

Ilinskiy, I. M. (2014) «Znanie - ponimanie - umenie» kak formula perspektivnoi nauchnoi i obrazovatel'noi politiki ["Knowledge - Understanding - Skill” as a Formula for a Long-Range Science and Education Policy]. Znanie. Ponimanie. Umenie, no. 1, pp. 5-17. (In Russ.).

Kuhn, T. (1977) Struktura naucbnykb revoliutsii [The structure of scientific revolutions]. Transl. by I. Naletov. Moscow, Progress Publ. 300 p. (In Russ.).

Meadows, D., Randers, J. and Meadows, D. (2007) Predely rosta: 30 let spustia [Limits to Growth: The 30-Year Update]. Moscow, Akademkniga Publ. 342 p. (In Russ.).

Submission date: 15.02 .2016$.

Плаксий Сергей Иванович - доктор философских наук, профессор, ректор Национального института бизнеса (г. Москва), вице-президент Союза негосударственных вузов Москвы и Московской области, заслуженный деятель науки РФ. Адрес: 111395, Россия, г. Москва, ул. Юности, д. 5, корп. 2. Тел.: +7 (499) 374-75-10. Эл. адрес: n_i_b@mail.ru

Plaksii Sergey Ivanovich, Doctor of Philosophy, Professor and Rector, National Institute of Business; Honored Scientist of the Russian Federation; Vice-President, Union of Nongovernmental Institutions of Higher Education of Moscow and Moscow Oblast. Postal address: Bldg. 2, 5 Yunosti St., Moscow, Russian Federation 111395. Tel.: +7 (499) 374-75-10. E-mail: n_i_b@mail.ru 